\title{
Bellow's Letters and Biographies about Bellow: A Book Review Article of New Work by Atlas and Taylo
}

\author{
Gustavo Sánchez-Canales \\ Autónoma University Madrid
}

Follow this and additional works at: https://docs.lib.purdue.edu/clcweb

(3)

Part of the Comparative Literature Commons, and the Critical and Cultural Studies Commons

Dedicated to the dissemination of scholarly and professional information, Purdue University Press selects, develops, and distributes quality resources in several key subject areas for which its parent university is famous, including business, technology, health, veterinary medicine, and other selected disciplines in the humanities and sciences.

CLCWeb: Comparative Literature and Culture, the peer-reviewed, full-text, and open-access learned journal in the humanities and social sciences, publishes new scholarship following tenets of the discipline of comparative literature and the field of cultural studies designated as "comparative cultural studies." Publications in the journal are indexed in the Annual Bibliography of English Language and Literature (Chadwyck-Healey), the Arts and Humanities Citation Index (Thomson Reuters ISI), the Humanities Index (Wilson), Humanities International Complete (EBSCO), the International Bibliography of the Modern Language Association of America, and Scopus (Elsevier). The journal is affiliated with the Purdue University Press monograph series of Books in Comparative Cultural Studies. Contact: <clcweb@purdue.edu>

\section{Recommended Citation}

Sánchez-Canales, Gustavo. "Bellow's Letters and Biographies about Bellow: A Book Review Article of New Work by Atlas and Taylo." CLCWeb: Comparative Literature and Culture 14.1 (2012): <https://doi.org/10.7771/ 1481-4374.1736>

This text has been double-blind peer reviewed by $2+1$ experts in the field.

The above text, published by Purdue University Press @Purdue University, has been downloaded 602 times as of $11 /$ $07 / 19$.

This document has been made available through Purdue e-Pubs, a service of the Purdue University Libraries. Please contact epubs@purdue.edu for additional information.

This is an Open Access journal. This means that it uses a funding model that does not charge readers or their institutions for access. Readers may freely read, download, copy, distribute, print, search, or link to the full texts of articles. This journal is covered under the CC BY-NC-ND license. 


\section{PURDUE}

U N T V E R S T T Y UNIVERSITY PRESS <http://www.thepress.purdue.edu>

\section{CLCWeb: Comparative Literature and Culture}

ISSN 1481-4374 <http://docs.lib.purdue.edu/clcweb> Purdue University Press @Purdue University

CLCWeb: Comparative Literature and Culture, the peer-reviewed, full-text, and open-access learned journal in the humanities and social sciences, publishes new scholarship following tenets of the discipline of comparative literature and the field of cultural studies designated as "comparative cultural studies." In addition to the publication of articles, the journal publishes review articles of scholarly books and publishes research material in its Library Series. Publications in the journal are indexed in the Annual Bibliography of English Language and Literature (Chadwyck-Healey), the Arts and Humanities Citation Index (Thomson Reuters ISI), the Humanities Index (Wilson), Humanities International Complete (EBSCO), the International Bibliography of the Modern Language Association of America, and Scopus (Elsevier). The journal is affiliated with the Purdue University Press monograph series of Books in Comparative Cultural Studies. Contact: <clcweb@purdue.edu>

\section{Volume 14 Issue 1 (March 2012) Article 14 \\ Gustavo Sánchez-Canales \\ "Bellow's Letters and Biographies about Bellow: \\ A Book Review Article of New Work by Atlas and Taylor" \\ <http://docs.lib.purdue.edu/clcweb/vol4/iss1/14>}

Contents of CLCWeb: Comparative Literature and Culture 14.1 (2012)

http://docs.lib.purdue.edu/clcweb/vol14/iss1/>

\section{Gustavo SÁNCHEZ-CANALES}

\section{Bellow's Letters and Biographies about Bellow: A Book Review Article of New Work by Atlas and Taylor}

It is interesting to contemplate why it took such a long time - and a couple of false starts - to write a biography of the Jewish American novelist Saul Bellow (1915-2005). At least two answers spring to mind: a first take on the question is that every attentive reader of Bellow's novels knows that no better biography could be written than his own books. To cite a few examples, his novel Humboldt's Gift (1975) is a fictionalized but accurate portrait of his ill-fated poet friend Delmore Schwartz and his relationship with him and Ravelstein (2000) is a memoir of his friendship with professor of philosophy Allan Bloom. Further resemblances between Bellow's friends and others include the fictional characters Moses Herzog, Herzog's villain Valentine Gersbach, Bellow's second wife's lover Jack Ludwig, Charlie Citrine's sweetheart Naomi Lutz in Humboldt's Gift, and Bellow's lover Margaret (Maggie) Staats, etc. In the "Introduction" to Conversations with Saul Bellow (1994), Gloria L. Cronin and Ben Siegel focus on the significance of Bellow's novels as a key to his life: "He is a strongly autobiographical fictionist whose probings of the self help explain his strong reliance on monologue. Indeed, Bellow's monologists usually share many of their creator's views, traits, and personal experiences. Those who know Bellow personally easily recognize themselves or other members of his circle of relatives and friends" (vii). A second answer can be found in Bellow's own ambivalence towards the matter of autobiography. On the one hand, as James Atlas explains, "Bellow fully expected biographies of him to be written: 'My father would be very unhappy if he thought no one was going to write his biography,' said his son Adam" (556). But at the same time, "biographers, [Bellow] said in a memorable image, were 'the shadow of the tombstone falling across the garden'" (Atlas 556). Apparently, Bellow's reluctance to enable a future biographer to write about his life stemmed, partly, not from his refusal to grant the biographer permission to access his letters, manuscripts, etc., but from his willingness and determination to leave his family members out of the biography, something unthinkable, ridiculous.

Mark Harris's Saul Bellow: Drumlin Woodchuck (1981) was the first attempt to write a biography of Bellow. The subtitle, which derives from Robert Frost's homonymous poem, points to the fact that Harris thought that his subject, like the woodchuck, "pretends that he and the world are friends." The book was written after the novelist refused to "endorse this book, nor has he in any way cooperated with the author in its formulation or in its writing" (n.p.). Although the would-be but frustrated 
biographer had access to Bellow's source material, Harris ended up publishing a comic book about not writing Bellow's biography. A decade later, Ruth Miller published Saul Bellow: A Biography of the Imagination (1991). Miller's book combines biographical facts with literary analysis of his works. However, at the last moment, after Bellow had given her full access to his archive of papers in the Regenstein Library and she had completed the book, Bellow changed his mind. He thought that the biography had become too personal and too dependent on gossip and when it was about to come out, Bellow threatened to sue Miller if she reproduced any of his personal letters or quoted any names of his family members. Hence, the title $A$ Biography of the Imagination. It took another decade to see Bellow's authorized biography, Saul Bellow: A Biography (2000). It was written by James Atlas, a good friend of the writer's. The publication of the book entailed, as in the case of Ruth Miller with Saul Bellow: A Biography of the Imagination, gradual estrangement from Bellow and eventual break-up. In Saul Bellow, Atlas explains that Harris had spent years asking Bellow to grant him permission to write his biography. Nervous by a rumour that had circulated prior to the 1981 book, the then would-be biographer Harris asked Bellow if it was true that he was writing his autobiography. The writer's answer was: "I wouldn't dream of writing my own autobiography ... There would be nothing much to say except that I have been unbearably busy ever since I was circumcised" (Atlas 442). And Benjamin Taylor starts his introduction to Saul Bellow: Letters (2010) by giving a similar explanation: "When urged to write his autobiography, Saul Bellow used to say there was nothing to tell except that he'd been unbearably busy ever since getting circumcised" (vii).

Before writing Saul Bellow, Atlas had published Delmore Schwartz: The Life of an American Poet (1977). That Saul Bellow is a far more accomplished book than Delmore Schwartz is probably owing to the fact that, apart from being more than twenty years older and gaining experience in those two decades, Atlas was more familiar with Bellow, counted on his cooperation, and Bellow is likely to be a more fascinating person and writer than Schwartz. Despite Atlas's familiarity with Bellow and his work - his biography of Schwartz had been praised by Bellow himself, Atlas and Bellow had a similar background, and the idea had also been suggested by Bellow's friend Philip Roth - Atlas was not sure if he would be able to accomplish the task. For that, he needed full access to the novelist's archive between Bellow and Atlas this was not a major problem - and Bellow's permission to cite without (too many) restrictions, which could be a problem. Atlas learned from the experiences of Harris and Miller that counting on Bellow's full cooperation was virtually impossible. Conscious of Samuel Beckett's famous edict to his first biographer, Deirdre Bair, Atlas knew that his subject would "neither help nor hinder" (Atlas xiv). Fully aware of Harris's and Miller's unsuccessful Bellow biographies, and despite his fear of writing a flattering biography, Atlas's Saul Bellow was successful. Far from giving an idealistic description of Bellow's personality, Atlas managed to present a detailed account of the novelist's intense life and literary career: his Jewish Canadian background, his several marriages and romances, teaching skills, professional (literary) discipline, awards and honors received, friendships and estrangements, critical responses to his works, real models for fictional characters, and many other aspects of Bellow's life which make Bellow and the biography a fascinating subject for study and analysis.

In the course of the writing of his book, Atlas met a number of people who had been angered by Bellow and whose friendship with him had broken forever. Probably this and some personal revelations like weaknesses, never-told secrets, etc., made by Atlas provoked the writer's subsequent hostility towards his biographer. After Atlas's difficulties and conflicts with Bellow throughout the writing of the biography, Atlas thanked Bellow for allowing him to write the biography saying that "Saul Bellow, a noted biographobe, eventually became reconciled, or at least resigned, to my presence in his life" (610). These words sound profoundly naïve and innocent if one knows that, in a letter addressed to the novelist and literary critic Richard Stern soon after the publication of the biography, Bellow's reconciliation with his biographer and (ex-) friend did not - and would never - take place: "I don't intend to read [James] Atlas. There is a parallel between his book and the towel with which the bartender cleans the bar. What strikes me uncomfortably about Atlas is that he has great appeal for my detractors. He was born to please them. Another match made in heaven" (Taylor 549).

The novelist's outrage against Atlas's biography should not distract the reader from the fact that this well-documented biography presents the first accurate picture of Bellow. One facet of his life which the book does not show, however, is his prolific, seventy-three-year span of letter writing. As 
Taylor explains in Saul Bellow: Letters, "when Moses Herzog undergoes the additional humiliation of being cuckolded by his best friend, the block lifts. He finds he can write - not, however, about Romanticism. What he manically scribbles is letters" (xiii-xiv). Moses Herzog, who "had fallen under a spell and was writing letters to everyone under the sun ... was so stirred by these letters that from the end of June he moved from place to place with a valise full of papers" (Herzog 1), behaves much the same as Bellow. For instance, in Herzog, Moses refers to his wife's lover Valentine Gersbach, among other things, as "a ringmaster, popularizer, liaison for the elites. He grabs up celebrities and brings them before the public. And he makes all sorts of people feel that he has exactly what they've been looking for. Subtlety for the subtle. Warmth for the warm. For the crude, crudity. For the crooks, hypocrisy. Atrocity for the atrocious. Whatever your heart desires. Emotional plasma which can circulate in any system" (Herzog 215). In the only letter addressed to Valentine's factual model, Jack Ludwig, collected in Letters, Bellow addresses his second wife Sondra Tschacbasov's lover in a similar tone. Among other things, he tells Ludwig that, "I trusted your taste and thought you might be reliable as an editor, but you are too woolly, self-absorbed, rambling, ill-organized, slovenly, heedless and insensitive to get on with. And you must be in a grotesque mess, to have lost your sense of reality to the last shred. I think you never had much of it to start with, and your letter reveals that that's gone, too" (Taylor 211).

Not only was Bellow's letter writing frantic but his trips as well. If one goes through Letters up to 1964, the year when Herzog was published, the reader finds that Bellow's letters were not only written in many parts of the United States (Chicago, New York, Michigan, Wisconsin, Minneapolis, New Jersey, Nevada, and San Francisco) but also outside of the U.S.: a great deal of them were sent from many places like Paris, Madrid, Freiburg, Bonn, Berlin, Rome, Positano, Belgrade, Tel Aviv, London, and Río Piedras (Puerto Rico). From 1965 to his last letter dated in 2004, he proved to be, like Herzog, a tireless writer and traveller who, apart from most of the aforementioned cities and towns also visited Boston and Nantucket, Aspen, Miami, Vermont and West Brattleboro, Pasadena, Victoria in British Columbia and Ontario, Saint-Martin (French West Indies), Bellagio, Oxford and Cambridge, Jerusalem and Almería. Taylor's book turns out to be an invaluable document where the reader can see, through Bellow's hundreds of letters between 1932 and 2004 the novelist's relationship with editors, fellow writers and friends, wives and ex-wives, sons, brothers, etc. In my opinion, what makes this book exceptional is that it shows Bellow in a lesser-known facet of his literary career and life. Taylor's Saul Bellow, which gathers letters that cover a time frame of three generations, casts not only an accurate self-portrait but also a rich portrait of an age.

We would be paying Bellow a disservice, however, if we boiled down his life and literary career to a mere enumeration of countless marital problems and break-ups, endless lawsuits, and the like which are detailed in The Letters. Beyond a descriptive account of the novelist's most controversial biographical facts is the figure of the indefatigable writer and correspondent, an often loyal friend and a committed writer and intellectual. If I had to choose among the hundreds of Bellow's letters, I would choose the ones he wrote to his fellow writers and friends. In these letters, we discover an unknownto-most-people Bellow. For instance, in his correspondence with John Berryman (Taylor 156-58, 16465,245 , etc.) we find a warm, affectionate Bellow preoccupied with the fragility of life and the difficulties of art. Writing to Ralph Ellison (Taylor 149-50, 170-72, 180, etc.), Bellow sounds frolicsome and loving. In the letters to fellow writers and friends like Roth, Bellow often seems reluctant to assume the role of senior literary mentor and in his letters to his literary peer (Taylor 162, 290, 322, 330 , etc.), the reader encounters a close, warm (but respectful) Bellow. In the letters addressed to Alfred Kazin one sees the evolution of their friendship from initial mutual respect and affection (Taylor 37-38, 137, 390, etc.) to eventual coldness and distancing (e.g., Taylor 317).

It is well known that Bellow was recipient of numerous awards and honours - to cite just a few, the Guggenheim Fellowship (1948), The National Book Award (1953, 1964, 1969), The French Croix de Chevaliers des Arts et des Lettres (1968), the Pulitzer Prize (1976), and the Nobel Prize (1976) but it is not so well known - in fact, almost unknown because there are virtually no references to this issue in Atlas's Saul Bellow or elsewhere - that he devoted a significant amount of time to writing letters to those same institutions which years before had bestowed an award on him. For instance, he wrote to the Swedish Academy proposing for the Nobel Prize in Literature fellow writers such as Robert Penn Warren (Taylor 436) and Roth (Taylor 546). Apart from the Swedish Academy, he also 
sent a letter to the Nobel Committee proposing the Nobel Peace Prize for Mayor Teddy Kollek of Jerusalem, "a statesman who believes that Middle Eastern differences can ultimately be reconciled and has indeed given the region, and the world as well, a practical demonstration that such a belief is not Utopian" (Taylor 426-27). Bellow also wrote to the John Simon Guggenheim Memorial Foundation in support of the application for fellowship of prominent figures in US-American literature like James Baldwin (Taylor 130), Bernard Malamud (Taylor 162), Grace Paley (Taylor 204), and Louise E. Glück (Taylor 284). And, finally, by writing to the American Academy and Institute of Arts and Letters, he expected Karl Shapiro's nomination for the Gold Medal in Poetry (Taylor 478). These letters - and many others - are a primary source of information on Bellow's selflessness towards other writers and friends.

From an early age, Bellow showed the centrality of death not only in his novels but also in his letters. Particularly well-written are his obituaries in memory of fellow writers and friends like Bernard Malamud (Taylor 435-36), Robert Penn Warren (Taylor 458), Ralph Ellison (Taylor 505-06), Eleanor Clark (Taylor 514-15), and his first sweetheart Yetta Barshevsky Shachtman (Taylor 527-29). In an interview with Jane Howard included in Conversations with Saul Bellow, he said that "the real problem $\ldots$ is the problem of death. If people don't know how to come to terms with it, and souls have no preparation, then the only thing is to be externally young and in pursuit of pleasure, and further sexual and hedonistic horizons" (Cronin and Siegel 82). This issue is also at the centre of the aforementioned memoir about Schwartz. In Humboldt's Gift, the protagonist-narrator Charlie Citrine says that "The main question, as Walt Whitman had pointed out, was the death question" (Bellow, Humboldt's Gift 332). The theme of death also pervades Ravelstein, a novel which provoked great commotion among many academic circles in the United States. In this memoir-like novel, Bellow disclosed a secret that most people ignored about Allan Bloom: that this conservative professor of philosophy was a homosexual who died after contracting AIDS and at every press conference Bellow gave after the publication of his novel, he had to explain why he had written such a book and Bellow's answer was always the same. The idea of writing the memoir stemmed from a promise he and Bloom had made to each other. According to the promise, if one of them outlived the other, the living friend would be in charge of writing a memoir of the other. Presumably, Bloom had specified that the task should be performed "without softeners or sweeteners" (Atlas 597). In Ravelstein, there are several references to the fact that Ravelstein/Bloom had asked Chich/Bellow to write his memoir following his imminent death $(14,59-60,128-29)$. It is clear, then, that the novel is "an account meant to commemorate and preserve Bloom's personality and life story" (Sánchez Canales, "Life, Death" 8). In reference to the masterly quality of Ravelstein, Atlas writes that "what makes Ravelstein such a satisfying work of biographical portraiture is the balance it strikes between the particular characteristics that Johnson considered essential to life-writing and the representative traits that make Ravelstein a subject worthy of sustained attention" (595). Despite all the commotion provoked by the disclosure of Bloom's secret, the novel received praise worldwide and some critics who dismissed Bellow, acknowledged the importance of his work (see, e.g., Birkerts).

Surprisingly, there is a wrote Bellow wrote to Werner Dannhauser - a scholar of political science - where Bellow, following Dannhauser's suggestion to "soften" the tone of some of his descriptions, acknowledges a few changes made in Ravelstein: "I promised to eliminate what you thought to be objectionable material and I wrote a revised version of Ravelstein. It took quite a lot of doing and the doing went against the grain (Taylor 545-46). Among other changes, Bellow excised the word HIV in a couple of sentences and, instead of using the word "AIDS" to refer to Ravelstein/Bloom's disease, he used "his condition." In this same letter, Bellow complains that "in the midst of this lengthy, timeconsuming and ultimately sterile procedure I remembered how displeased Bloom had been with The Dean's December. He objected to the false characterization of Alexandra and he didn't spare me one bit" (Taylor 546). Unfortunately, there are no further references to this issue in Taylor's Letters or Atlas's Saul Bellow: there is only mere speculation.

In conclusion, while Atlas's Bellow: A Biography is a detailed account of the novelist's personal and professional life and that reveals a portrait of one of the most gifted and talented literary figures in US-American letters, Taylor's Saul Bellow: Letters shows a less well-known facet of the human being who wrote incredibly acute, funny, tender, and witty letters to friends, wives, lovers, colleagues and fans for a seventy-year time span. 


\section{Works Cited}

Atlas, James. Delmore Schwartz: The Life of an American Poet. New York: Farrar, Straus \& Giroux, 1977. Atlas, James. Saul Bellow: A Biography. New York: Modern Library, 2000.

Bellow, Saul. Herzog. New York: Viking P, 1964.

Bellow, Saul. Humboldt's Gift. New York: Viking P, 1975.

Bellow, Saul. Ravelstein. New York: Viking P, 2000.

Bellow, Saul. The Actual. New York: Penguin, 1997.

Bellow, Saul. The Dean's December. New York: Harper \& Row, 1982.

Birkerts, Sven. "The Last Titan." Esquire (2000): 70-71.

Cronin, Gloria L., and Ben Siegel, eds. Conversations with Saul Bellow. Jackson: UP of Mississippi, 1994.

Harris, Mark. Saul Bellow: Drumlin Woodchuck. Athens: U of Georgia P, 1981.

Miller, Ruth. Saul Bellow: A Biography of the Imagination. New York: St. Martin's P, 1991.

Sánchez Canales, Gustavo. "Life, Death and Aristophanes' Concept of Eros in Saul Bellow's Ravelstein." Saul Bellow Journal 19.3 (2003): 8-18.

Taylor, Benjamin, ed. Saul Bellow: Letters. New York: Viking, 2010.

Reviewer's profile: Gustavo Sánchez-Canales teaches English at Autónoma University Madrid. His interests in research include contemporary Jewish American fiction, Holocaust literature, and literary theory. He has published numerous articles in Spanish and English on the work of authors including Philip Roth, Saul Bellow, Bernard

Malamud, Chaim Potok, Cynthia Ozick, Allegra Goodman, and Jonathan Safran Foer. His recent publications include "About Society: A Book Review Article of Work on Roth and Kundera by Shostak and Ivanova," CLCWeb: Comparative Literature and Culture (2011) and "The Classical World and Modern Academia in Philip Roth's The Human Stain," Philip Roth Studies (2009). E-mail: <gustavo.sanchez@uam.es> 